\title{
The Influences of Basic Physical Properties of Clayey Silt and Silty Sand on Its Laboratory Electrical Resistivity Value in Loose and Dense Conditions (Pengaruh Sifat Fizikal Asas Kelodak Lempung dan Pasir Berkelodak pada Nilai Kerintangan Elektrik Makmal dalam Keadaan Longgar dan Padat)
}

\author{
MOHD HAZREEK ZAINAL ABIDIN*, ROSLI SAAD, DEVAPRIYA CHITRAL WIJEYESEKERA, FAUZIAH AHMAD,

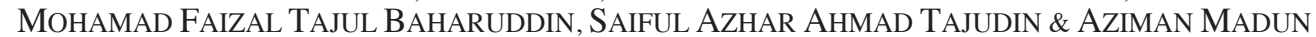

\begin{abstract}
Non-destructive test which refers to electrical resistivity method is recently popular in engineering, environmental, archaeological and mining studies. Based on the previous studies, the results on electrical resistivity interpretation were often debated due to lack of clarification and evidences in quantitative perspective. Traditionally, most of the previous result interpretations were depending on qualitative point of view which is risky to produce unreliable outcomes. In order to minimise those problems, this study has performed a laboratory experiment on soil box electrical resistivity test which was supported by an additional basic physical properties of soil test like particle size distribution test (d), moisture content test $(w)$, density test $\left(\rho_{\text {bulk }}\right)$ and Atterberg limit test (LL, PL and PI). The test was performed to establish a series of electrical resistivity value (ERV) with different quantity of water content for clayey silt and silty sand in loose and dense condition. Apparently, the soil resistivity value was different under loose $(L)$ and dense $(C)$ conditions with moisture content and density variations (silty SAND $=E R V_{\text {Loose }}: 600-7300 \Omega m \& E R V_{\text {Dense }}: 490-7900 \Omega m$ while Clayey SILT = $E R V_{\text {Loose }}: 13-7700 \Omega m \& E R V_{\text {Dense }}: 14-8400 \Omega m$ ) due to several factors. Moreover, correlation of moisture content (w) and density $\left(\rho^{\text {bulk }}\right)$ due to the ERV was established as follows; Silty SAND: $w^{(L)}=638.8 \rho^{-0.418}, w^{(D)}=1397.1 \rho^{-0.574}, \rho_{B u k(L)}=$ $2.6188 e^{-6 E-05 \rho}, \rho_{\text {Bulk(D) }}=4.099 \rho^{-0.07}$ while Clayey SILT: $w_{(L)}=109.98 \rho^{-0.268}, w_{(D)}=121.88 \rho^{-0.363}, \rho_{\text {Bulk }(L}{ }^{\prime}=-0.111 \ln (\rho)+1.7605$, $\rho_{\text {Bulk(D) }}=2.5991 \rho^{0.037}$ with determination coefficients, $R^{2}$ that varied from $0.5643-0.8927$. This study was successfully demonstrated that the consistency of ERV was greatly influenced by the variation of soil basic physical properties $(d, w$, $\rho_{B u l k}, L L, P L$ and PI). Finally, the reliability of the ERV result interpretation can be enhanced due to its ability to produce a meaningful outcome based on supported data from basic geotechnical properties.
\end{abstract}

Keywords; Basic geotechnical properties; basic physical properties of soil; correlation of moisture content and density; laboratory electrical resistivity

\section{ABSTRAK}

Ujian tak musnah yang merujuk kepada kaedah kerintangan elektrik semakin banyak digunakan dalam kajian kejuruteraan, alam sekitar, arkeologi dan perlombongan. Berdasarkan kajian terdahulu, interpretasi keputusan kerintangan elektrik sering diperdebatkan disebabkan kekurangan bukti kajian dalam perspektif kuantitatif. Kebiasaannya interpretasi keputusan kerintangan elektrik banyak bergantung kepada perspektif kualitatif justeru berkemungkinan besar berisiko tinggi untuk menghasilkan keputusan yang salah. Maka, kajian ini telah menjalankan uji kaji makmal kerintangan elektrik tanah disokong oleh uji kaji sifat asas fizikal tanah seperti uji kaji taburan saiz zarah (d), kandungan lembapan (w), ketumpatan $\left(\rho_{\text {bulk }}\right)$ dan had Atterberg (LL, PL dan PI). Uji kaji dijalankan untuk menghasilkan satu siri nilai kerintangan elektrik (ERV) berdasarkan kuantiti air yang berbeza terhadap lempung berkelodak dan kelodak berpasir dalam keadaan longgar dan juga mampat. Hasil keputusan menunjukkan nilai kerintangan tanah adalah berbeza dalam keadaan longgar $(L)$ dan mampat $(C)$ serta variasi kandungan air dan juga ketumpatan (pasir berkelodak $=E R V_{\text {Longgar }}: 600-7300 \Omega \mathrm{m}$ $\& E R V_{\text {Mampat }}: 490-7900 \Omega m$ sementara lempung berkelodak $\left.=E R V_{\text {Longgar: }}: 13-7700 \Omega m \& E R V_{\text {Mampat: }}: 14-8400 \Omega m\right)$ disebabkan beberapa faktor. Selain daripada itu, korelasi kandungan lembapan $(w)$ dan ketumpatan $\left(\rho_{\text {bulk }}\right)$ terhadap ERV telah diterbitkan seperti berikut; pasir berkelodak: $w_{(L)}=638.8 \rho^{-0.418}, w_{(D)}=1397.1 \rho^{-0.574}, \rho_{B u l k(L)}=2.6188 e^{-6 E-05 \rho}, \rho_{B u l k(D)}$ $=4.099 \rho^{-0.07}$ sementara pasir berkelodak: $w_{(L)}=109.98 \rho^{-0.268}, w_{(D)}=121.88 \rho^{-0.363}, \rho_{\text {Bulk }(L)}=-0.111 \ln (\rho)+1.7605, \rho_{\text {Bulk(D) }}$ $=2.5991 \rho^{0.037}$ dengan pekali dapatan, $R^{2}$ bervariasi lingkungan 0.5643 - 0.8927 . Kajian ini telah berjaya menunjukkan bahawa tahap kekonsistenan nilai ERV boleh dipengaruhi oleh variasi nilai sifat asas fizikal tanah $\left(d, w, \rho_{B u k}, L L, P L\right.$ dan PI). Maka, kebolehpercayaan terhadap interpretasi nilai ERV boleh dipertingkatkan kerana kemampuannya untuk menghasilkan keputusan bermakna berdasarkan sokongan data daripada sifat asas geoteknik.

Kata kunci: Kaedah kerintangan elektrik; kolerasi terhadap kandungan lembapan dan ketumpatan; sifat asas fizikal tanah; sifat asas geoteknik 


\section{INTRODUCTION}

Geotechnical site investigation work is commonly carried out in order to determine the properties of the geomaterials (i.e. soil and rock) that involves surface and subsurface exploration such as physical mapping, soil sampling and laboratory testing. Commonly, physical mapping (geological mapping) is always adopted for surface exploration while soil sampling and laboratory test are usually performed for subsurface exploration. Classically, drilling technique (i.e. borehole method) has widely used to obtain site investigation data due to its good data accuracy derived from direct test approach. However in certain cases (large scale project), this traditional drilling method experienced several difficulties and limitations related to low efficiency of the project cost, time and data coverage. Moreover, the information obtained was a localized single point data thus promoting to the increment of uncertainties degree of subsurface profile investigated thru interpolation between large borehole data (Godio et al. 2006; Mauritsch et al.2000). As a result, the solutions to these challenges will require multidisciplinary research across the social and physical sciences and engineering (Fragaszy et al. 2011). Hence, geophysical method offers the chance to overcome some of the problems inherent in more conventional ground investigation techniques (Clayton et al. 1995).

Nowadays, geophysical method has improved due to continuous and rapid advancement of electronics technology thus increasingly adopted as an alternative tool in site investigation works. Geophysical methods can be implemented more quickly and less expensively and can cover larger areas more thoroughly (Cosenza et al. 2006; Godio et al. 2006; Khatri et al. 2011; Liu $\&$ Evett 2008). The electrical resistivity method (ERM) has widely used as an alternative geophysical tool in geotechnical site investigation due to its good ability to map and to characterise the subsurface profile indirectly from the surface. From past experience, electrical resistivity method was heavily performed as a detection and mapping tool related to the determination of depth and thickness of soil and rock, bedrock and overburden materials (Akturk \& Doyuran 2015; Hazreek et al. 2015; Hsu et al. 2009; Sass 2007; Saad et al. 2011; Samsudin et al. 2007), groundwater (Abidin et al. 2015; Afshar et al. 2015; Ebraheem et. al. 2014; Hamzah et al. 2009a, 2006a, 2006b), landslides (Abidin et al. 2012; Hamzah et al. 2009b; Nouioua et al. 2015), cavity (Abdallatif et al. 2015; Abu-Shariah 2009; Billi et al. 2016; Jusoh 2010; Margiotta et al. 2015; Martinez-Pagan et al. 2010; Schoor 2002), boulder (Hajizadeh \& Akhondi 2016; Taioli et al. 2009), environmental (Al-Sabahi et al. 2008; Baharuddin et al. 2013; Cuong et al. 2016; Hamzah \& Chieh 2008; Hamzah et al. 2009c; Jeeva \& Hamzah 2012; Liu et al. 2015; Moghaddam et al. 2015; Mohamed et al. 2009; Sirhan \& Hamidi 2013) and archaeology (Hafez et al. 2008; Hawamdeh et al. 2015; Masrom et al. 2011; Reci et al. 2015; Terrón et al. 2015). Traditionally, most of the projects involving ERM performed by respective parties possessed their own strength and weakness based on their own experience and knowledge. For example, geophysicists are the early champion in geophysical areas and thus, allows them to perform the entire electrical resistivity method (i.e. data acquisition, processing and interpretation) very well compared to the civil engineers and geologist that lack of fundamental and experienced in geophysical techniques.

In the past, traditional electrical resistivity interpretation was subjectively rely on image anomaly and past geomaterials reference charts and tables which exposed to the results verification and reliability argument due to its qualitative interpretation dependent. For example, the properties of ERV can be found to be dissimilar even for the same particular type of geomaterials in many past references. Moreover, conventional reference tables of geomaterials used for anomaly interpretation were sometimes difficult to decipher due to wide range of variation and overlapping values (Solberg et al. 2011). As a result, strong result verification is important to clarify its behaviour which was conventionally concluded according to the qualitative approach which was relative to the individual experience and expert (Abidin et al. 2013). Hence, geophysical properties ambiguity needs to be discovered and reduced in order to produce convincing and meaningful results. Geophysical methods are unable to stand alone in order to provide solutions to any particular problems (Benson \& Kaufmann 2003; Fraiha \& Silva 1994). According to (Clayton et al. 1995), geophysicists express little appreciation from the engineer's point of views and lack of the knowledge on the science in soil mechanics.

Studies relating geophysical data with geotechnical properties are rare and less known (Cosenza et al. 2006). Hence, this study was performed to establish a series of laboratory soil electrical resistivity properties and basic physical properties (BPP) under controlled environment. The aim of this study was to reduce black boxes and ambiguities between all related parties via demonstrating the relationship of ERV and basic physical properties of soil with particular reference to moisture content, density and soil grain size characteristics. Laboratory test performed was able to reduce soil electrical resistivity result ambiguities thus produced significant outcome due to its control environment (temperature, humidity and properties known). Finally, this fundamental research may contribute to the respective parties in term of results reliability confidence level due to its quantitative interpretation of ERV thru basic physical properties of soil. The rest of the papers are organized as follows.

\section{MATERIALS AND METHODS}

All tests were based on laboratory work via geotechnical and geophysical (Laboratory Electrical Resistivity) experiments. Two types of soil representing coarse soil (Silty SAND) and fine foil (Clayey SILT) were used in this study due to the comparison purposes. Further explanation regarding sampling, geotechnical testing, geophysical testing, basic physical properties of soil and statistical 
analysis were presented in subsection A - D. Overall study methods was given in Figure 1.

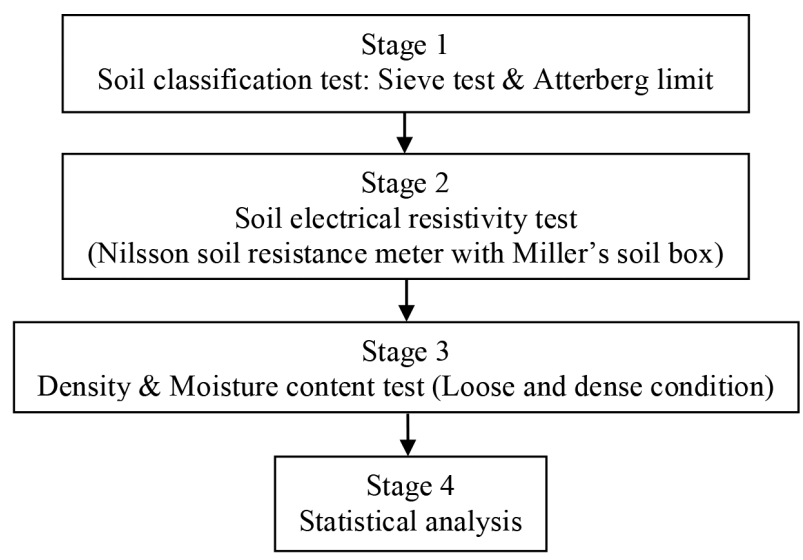

FIGURE 1. Analysis path to infer basic physical properties of soil influence on its laboratory electrical resistivity value in loose and dense soil condition

\section{SAMPLING}

Soil sampling was based on disturbed samples obtained from Universiti Sains Malaysia. This study used disturbed soil samples due to its sufficiency to perform and obtained basic physical properties of soil. Quantity of soil sample (Silty SAND and Clayey SILT) used for laboratory electrical resistivity test was $1500 \mathrm{~g}$ of oven dried soil which adequate to produce a series of electrical resistivity, soil moisture content and density data.

\section{GEOTECHNICAL TESTS}

Geotechnical test performed in this study was based on basic physical properties of soil testing as referred to British Standards 1377 (1990). Those related testing were based on soil classification tests related to particle size distribution (PSD) test specifically adopting the dry and wet sieve techniques, Atterberg limit test, moisture content using oven drying method and density test.

\section{GEOPHYSICAL TESTS}

Geophysical test adopted in this study was based on laboratory electrical resistivity experiment. This experiment was performed using soil box electrical resistivity test specifically thru Nilsson's soil resistance meter and Miller's soil box. Soil box electrical resistivity test was performed by mixing an original mass of $1500 \mathrm{~g}$ of oven dried soil with 1-3\% of distilled water and tested repeatedly for 25 times (each test used 15,30 and $45 \mathrm{~mL}$ of distilled water based on percentage of water used for $1500 \mathrm{~g}$ of soil). For example, a $15 \mathrm{~mL}$ of distilled water was added consistently and mixed thoroughly into the originally oven dried soil and continuously tested with each increment of distilled water added using soil box resistivity meter for 25 determinations of soil resistivity value. After that, the same procedure was repeated using a 30 and $45 \mathrm{~mL}$ of distilled water. In other words, three (3) soil samples for clayey silt (sample A, B and C) and gravelly sand (sample A, B and C) was prepared separately for soil box electrical resistivity test under different denseness (loose and dense) condition. Each sample (A, B and C) was tested for 25 numbers of data due to consistency purposes. This study found that the best maximum sample number of soil box electrical resistivity data recorded is 25 since the consistency of electrical resistivity value (ERV) has reach its best thus confirm the results obtained.

The measurement was performed in both a loose and dense condition. Under the loose condition, soil was placed inside the box without being forced (simulated based on free fall condition) while the dense condition required the soil to be compacted by generating impact through hammering on a fully flat wooden plate that was fully fitted and placed inside of the soil box. The hammering process was completed step by step in three layers where each layer was compacted with a consistent energy for 27 impacts in order to generate the best uniform compacted soil.

Soil box resistivity meter consisted of a 4 pin arrangement consisting of 2 current pin (both being located at the end of the soil box) and 2 potential pin (these being located along the middle of the soil box). The function of two end current pins were to inject direct current (DC current) into the soil while the other two potential pins were used to measure a potential difference for calculating the soil resistivity value. Soil moisture content and density was taken immediately after the soil resistivity was measured.

\section{PARAMETER INVESTIGATED}

This study was focused on the influence of soil basic physical properties due to the laboratory electrical resistivity variations in loose and dense condition. Basic physical properties of soil were related to solid, water and air which able to represent thru moisture content, density, grain size fraction, void ratio and porosity. Based on this study, moisture content test was determined for two samples from each soil box test for final averaging purposes. As referred to British standard 1377 (1990), the following equations 1 - 3 were used to calculate the soil resistivity value, moisture content and bulk density.

$$
\rho=R A / L
$$

where A is the cross-sectional area of the sample; $\mathrm{L}$ is the length of the sample between the electrodes; and $\mathrm{R}$ is the mean resistance of the soil sample $(\mathrm{R}=\mathrm{V} / \mathrm{I})$

$$
\rho_{\text {bulk }}=m / V
$$

where $\mathrm{m}$ is the mass of the soil specimen (solids + water); and $\mathrm{V}$ is the volume of the test specimen (total volume)

$$
w=\left(\left(m_{2}-m_{3}\right)\left(m_{3}-m_{1}\right)\right) \times 100,
$$


where $\mathrm{m}_{1}$ is the mass of container; $\mathrm{m}_{2}$ is the mass of container; and wet soil and $\mathrm{m}_{3}$ is the mass of container and dry soil.

\section{STATISTICAL ANALYSIS}

All results obtained from the experiments were analysed using a statistical regression method. Statistical Package for the Social Sciences (SPSS) software was performed to determine the correlation coefficient, $r$ while coefficient of determination, $\mathrm{R}^{2}$ was determined using Microsoft Excel. All the laboratory test data was analyzed for $\mathrm{r}$ based on $1 \%, 2 \%$ and $3 \%$ of water concentration in order to determine the best relationship between all those parameter studied (electrical resistivity, moisture content and density of soil).

Correlation coefficient, $r$ or also known as Pearson's correlation coefficient is the most familiar method to measure dependence between two quantities or parameter. Moreover, strength of linear relationship between parameter studied can be obtained and verified statistically based on $r$ value analyzed. According to Yahaya et al. (2008), strength of linear relationship can be conclude based on its $r$ value which varies from $1.00-0.8$ (very strong), $0.79-0.6$ (strong), $0.59-0.4$ (medium), $0.39-0.2$ (weak) and $0.19-0.00$ (very weak). Linear relationship between two variables, $\mathrm{x}$ and $\mathrm{y}$ was measured by correlation coefficient, $r$ given in (4) (Yahaya et al. 2008).

$$
r=\frac{N \Sigma x y-(\Sigma x)(\Sigma y)}{\sqrt{\left[N \Sigma x^{2}-(\Sigma x)^{2}\right]\left[N \Sigma y^{2}-(\Sigma y)^{2}\right]}}
$$

where $\mathrm{x}, \mathrm{y}$ are two different parameters; and $\mathrm{N}$ is size of the sample.

Statistically, $\mathrm{R}^{2}$ value give an indicator on how well the data fit a statistical model based trend line (line or curve). Hence based on $\mathrm{R}^{2}$ analysis using Microsoft Excel package, determination of $\mathrm{R}^{2}$ value was varied relatively to best data that fits the trend line thru exponential, linear, logarithmic, polynomial or power. In this study, $\mathrm{R}^{2}$ value was decide based on the best trend line (line or curve) that perfectly fits the statistical model. As reported by Yahaya et al. (2008), coefficient of determination, $\mathrm{R}^{2}$ range of values is $0 \leq R^{2} \leq 1.0$. The nearest value of $R^{2}$ to 1.0 and 0 indicate that the regression line was perfectly fits the data and the line does not fit the data at all, respectively. Coefficient of determination, $\mathrm{R}^{2}$ was obtained based on (5). Finally, prediction of future outcomes (parameter studied) was obtained by the trend line equation produced based on the best of $\mathrm{R}^{2}$ (nearest to 1.0) value obtained.

$$
\mathrm{R}^{2}=1-(\mathrm{SSE} / \mathrm{SYY}),
$$

where SSE is residual sum of squares; and SYY is total sum of squares.

\section{RESULTS AND DISCUSSION}

All results presented and discussed were based on basic physical properties of soil, laboratory electrical resistivity value (ERV) and relationship of laboratory ERV with moisture content $(w)$, density $(\rho)$ and grain size of soil (d). All results are presented in Table 1 and Figures 2 - 4.

\section{PARTICLE SIZE FRACTION, ATTERBERG LIMIT, MOISTURE CONTENT AND DENSITY}

This study was performed using two different types of soil which are represented as fine (soil 1) and granular (soil 2) soils to demonstrate the influence between ERV and soil with different composition of physical and chemical properties. According to the sieve and Atterberg limit test, it was found that the fine soil sample tested is classified as Clayey SILT (a mixture of granular and fine particle with the domination of fine size particle) while granular soil sample tested is known as Silty SAND (a mixture of granular and fine particle with the domination of granular size particle). All sieve analysis results from both soil specimen were found to be varied in terms of particle size quantification due to the natural heterogeneity features of soil as shown in Table 1 and Figure 2. The Atterberg limit test was conducted in accordance to British standard 1377 (1990) to determine the soil consistency limits due to the high silt content detected from sieve analysis test. The plasticity index (PI) and liquid limit (LL) obtained from all soil samples tested are $12.1 \%$ and $51.9 \%$ (Clayey SILT) and $7.25 \%$ and $38.40 \%$ (Silty SAND). According to the Casagrande soil classification, soil 1 (Clayey SILT) is classified as SILT with high plasticity (MH) while soil 2 (Silty SAND) is classified as SILT with intermediate plasticity (MI). Soil 2 was found to be intermediate plasticity due to the existing of high granular particle as proven by sieve test result. Hence, soil 1 is finally categorized as Clayey SILT while soil 2 is classified as Silty

TABLE 1. Quantification of soil classification tested based on

\begin{tabular}{|c|c|c|c|}
\hline Soil sample & Material & Quantity, \% & Quantity, \% \\
\hline \multirow{5}{*}{ Clayey SILT } & Clay & $\begin{array}{l}24.82 \\
5408\end{array}$ & 78.90 \\
\hline & $\begin{array}{c}\text { Sand } \\
\text { Gravel }\end{array}$ & $\begin{array}{c}16.51 \\
4.59\end{array}$ & 21.10 \\
\hline & LL & \multicolumn{2}{|c|}{51.90} \\
\hline & PL & \multicolumn{2}{|c|}{39.80} \\
\hline & PI & \multicolumn{2}{|c|}{12.10} \\
\hline \multirow{5}{*}{ Silty SAND } & $\begin{array}{l}\text { Clay } \\
\text { Silt }\end{array}$ & $\begin{array}{c}3.40 \\
36.51\end{array}$ & 39.91 \\
\hline & $\begin{array}{l}\text { Sand } \\
\text { Gravel }\end{array}$ & $\begin{array}{l}47.35 \\
12.74\end{array}$ & 60.09 \\
\hline & LL & \multicolumn{2}{|c|}{38.40} \\
\hline & PL & \multicolumn{2}{|c|}{31.15} \\
\hline & PI & \multicolumn{2}{|c|}{7.25} \\
\hline
\end{tabular}
PSD and Atterberg limit test 


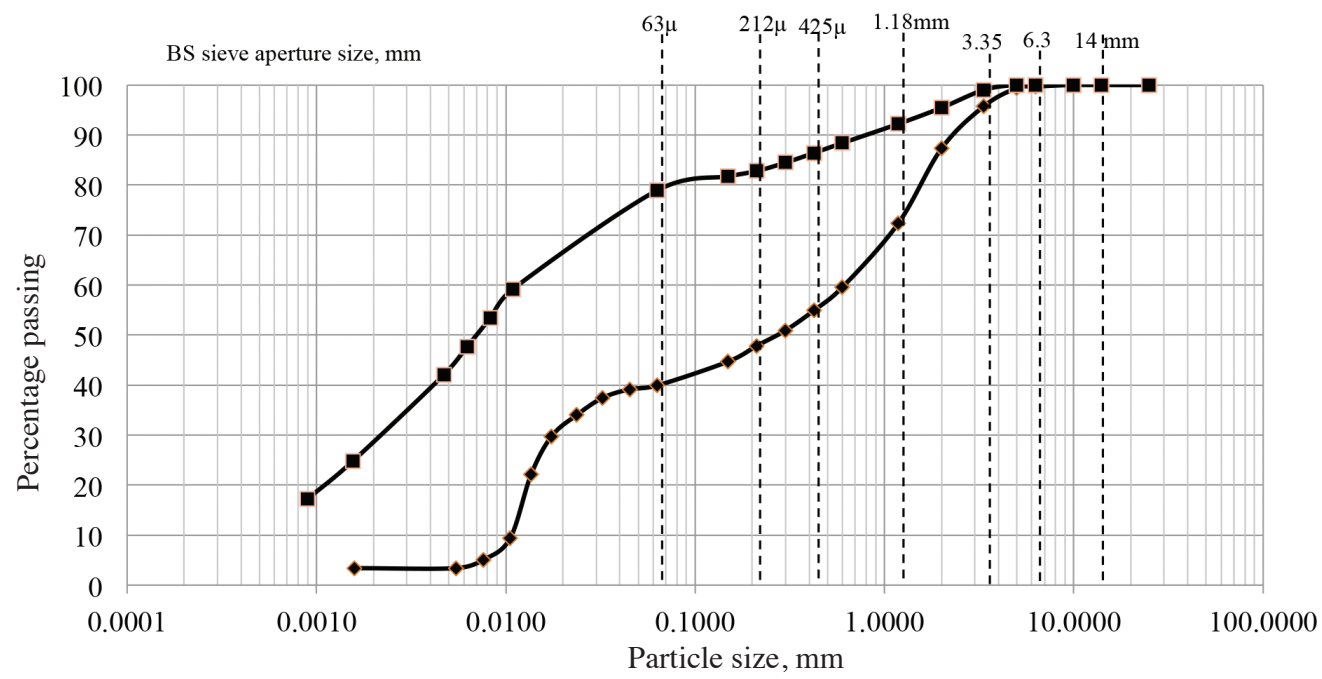

$\longrightarrow$ - Silty SAND $\quad-\backsim-$ Clayey SILT

FIGURE 2. PSD curve for Clayey SILT and Silty SAND from dry and wet sieve analysis

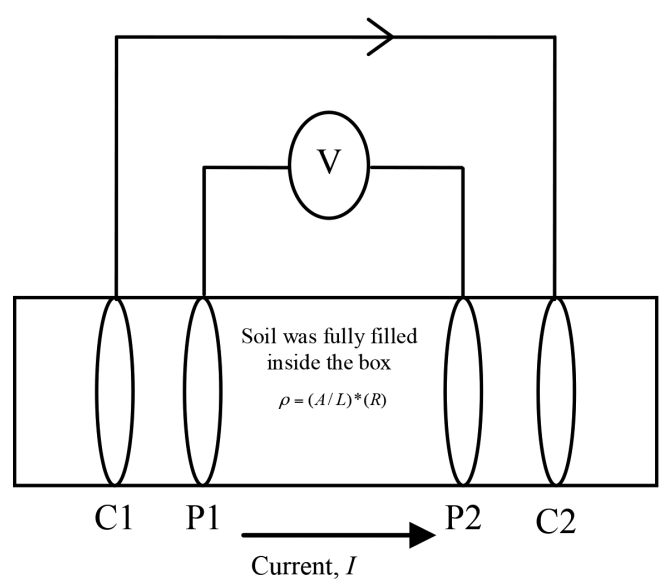

FIGURE 3. Soil box resistivity measurement with its geometry factor, $\mathrm{K}$

SAND based on the combination of sieve and Atterberg limit results. The variation in Atterberg limit values can be influenced by several factors such as particle size and shape. For example as reported by Whitlow (2001), the engineering properties of fine soils such as silts and clay are highly influenced by their shape rather than size of particle. Fine soils such as clay and silts are usually flaky plates in shape. The variation in the Atterberg limits may result in the different flaky shapes mixed with other materials that cause the water content to change for all the soil tested. Thus, under such circumstances, the geotechnical properties are natural variable.

Soil moisture content was determined by the ratio of water mass to the solids mass. Basically, soil moisture content knowledge is essential in all studies of soil mechanics which ables to give an idea of the state of soil thus contributes to the design and construction input of civil engineering structures. In loose condition, it was found that soil moisture content $(w)$ of Clayey SILT and Silty SAND was recorded as $7.76-100 \%$ and 17.66 - $61.07 \%$, respectively, while soil density of both soils was recorded as $1.00-1.69 \mathrm{Mg} / \mathrm{m}^{3}$ and $1.77-2.66 \mathrm{Mg} /$ $\mathrm{m}^{3}$, respectively. In dense condition, soil moisture content (w) was recorded as $5.22-93.70 \%$ and $9.80-59.05 \%$, respectively, while soil density of both soils were recorded as $1.96-2.58 \mathrm{Mg} / \mathrm{m}^{3}$ and $2.16-2.80 \mathrm{Mg} / \mathrm{m}^{3}$, respectively. In soil mechanics and geotechnical engineering, soil density is basically described using bulk density $\left(\rho_{\text {bulk }}\right)$ and dry density $\left(\rho_{\text {dry }}\right)$. Bulk density is defined by the total mass of solids and water per total volume while dry density is defined by mass of solids per total volume. Quantities of densities provide a measure of the material quantity related to the space amount it occupies (Whitlow 2001). Based on Figures $4-7$, it can be observed that the densities of each soil were relative to the moisture content variations which represent general relationship of soil densities linearly proportional to the moisture content $(\rho \alpha \mathrm{w})$. High quantity of water will add the total weight of soil thus increasing its density and vice versa. Quantity of fine particles from Clayey SILT was greater than coarse particle thus allowed more water to be absorbed which finally increased its densities. Besides, Silty SAND relationship due to density was strongly believed to be influenced by the domination of water and coarse grain particle. Coarse grain soil has low ability to absorb water but has high ability in term of its mass. Hence, the value of moisture content (w) of Silty SAND was lower than Clayey SILT but higher in density due to the greater mass of coarse particle together with the existence of water. Generally, both types of soil have demonstrated a variation of moisture content and density due to the dissimilarity composition of particle sizes fraction. However, it was found that all variations of the 
basic physical properties of soil obtained were also relative to the different degree of soil denseness (loose and dense state).

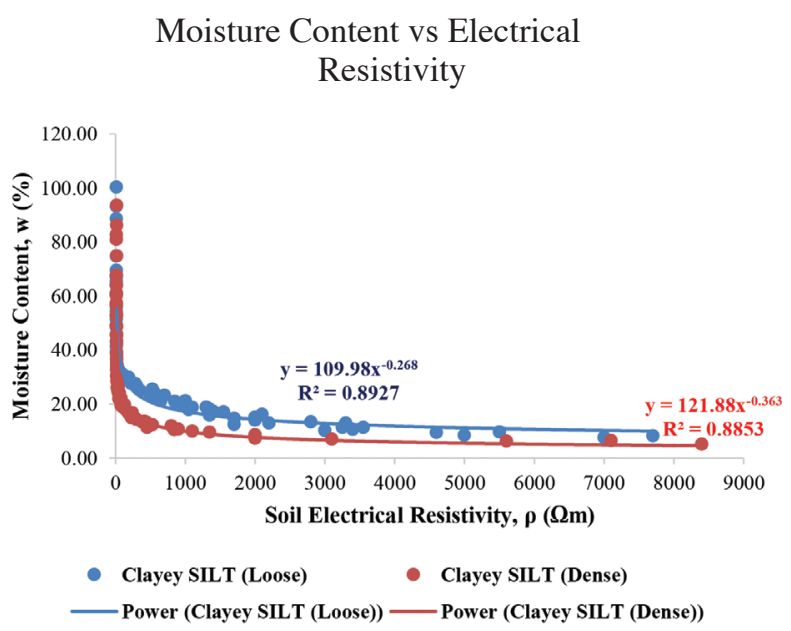

FIGURE 4. Moisture content correlation with ERV for Clayey SILT

Bulk Density vs Electrical Resistivity

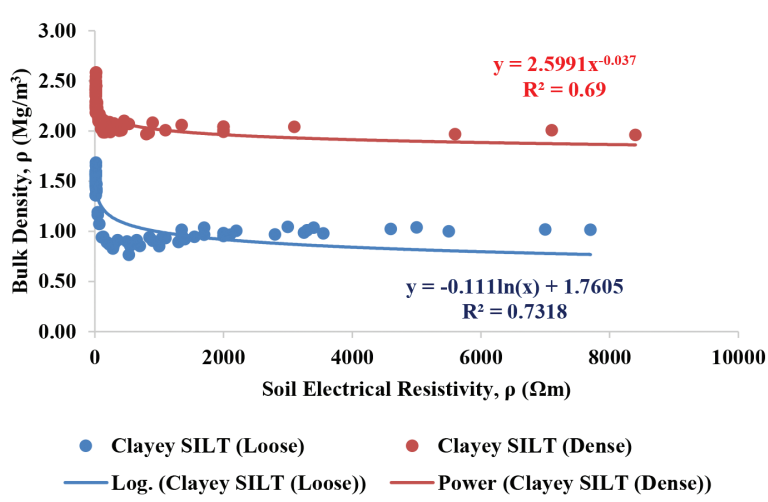

FIGURE 5. Density (right) correlation with ERV for Clayey SILT

Moisture Content vs Electrical Resistivity

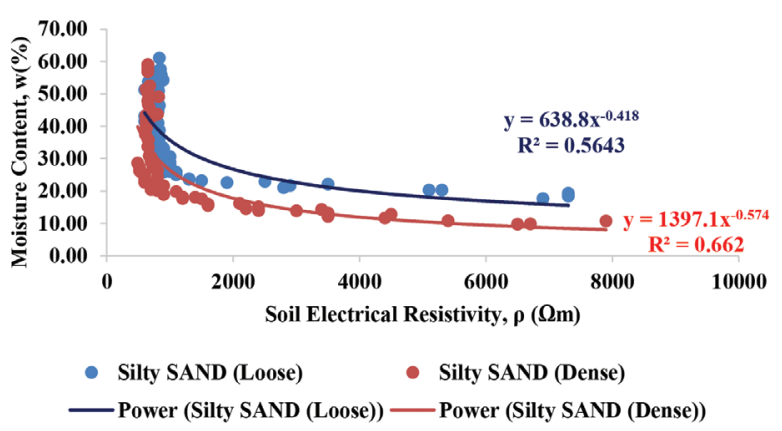

FIGURE 6. Moisture content correlation with ERV for Silty SAND
Bulk Density vs Electrical Resistivity

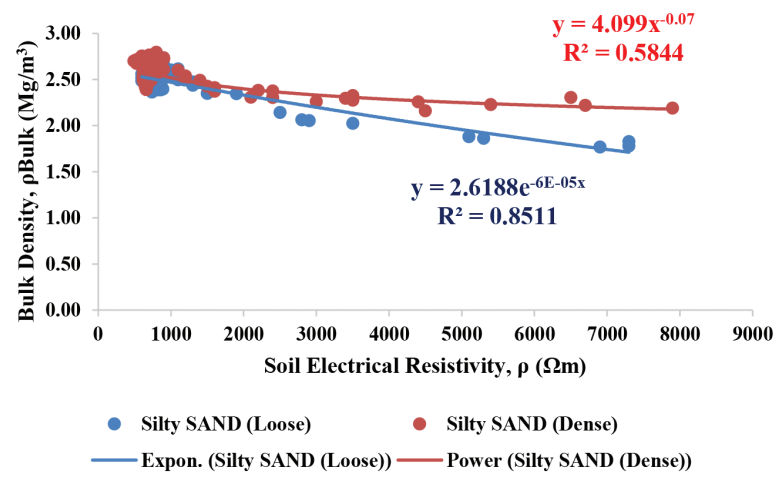

FIGURE 7. Density correlation with ERV for Silty SAND

\section{ELECTRICAL RESISTIVITY VALUE (ERV)}

ERV was determined by measuring the potential difference at points on the ground surface which caused the propagation of direct current through the subsurface (Burger et al. 2006). The value of apparent ERV $\left(\rho_{\mathrm{a}}\right)$ was greatly influenced by $\mathrm{K}$ factor applied in every measurement. The ERV was largely influenced by types of array used due to the different geometry factor $(\mathrm{K})$ derived from each different types of array used (Abidin et al. 2014a, 2014b). Geometry factor, K describes the geometry of the electrode configuration used in data acquisition. Apparent resistivity $\left(\rho_{\mathrm{a}}\right)$ is ERV estimated based on half-pace geometry assumption which refers to the field ERV. According to Telford et al. (1990), apparent resistivity will be equal to the true resistivity provided the current and configuration were applied over the homogeneous isotropic ground. However, lab ERV was determined using soil box apparatus with simple geometry factor as given in (1). The ERV obtained in Table 2 was originally established from the laboratory soil box test using two different types of soil under loose and dense condition. In loose condition, it was found that the ERV of Clayey SILT and Silty SAND were recorded as 13 - $7700 \Omega \mathrm{m}$ and 600 - $7300 \Omega \mathrm{m}$, respectively, while the ERV of Clayey SILT and Silty SAND in dense condition were recorded as $14-8400 \Omega \mathrm{m}$ and $490-7900 \Omega \mathrm{m}$, respectively. It was found that soil in dense condition has shown a higher ERV value compared to the ERV in loose condition due to the different composition of basic physical properties of soil such as solid, water and air. Electrical propagation in soil is largely electrolytic process by flowing in connected pore spaces and along grain boundaries of geomaterial (Anita 2005).

BEHAVIOUR OF ELECTRICAL RESISTIVITY VALUE (ERV) DUE TO THE INFLUENCES OF SOIL BASIC PHYSICAL PROPERTIES IN LOOSE AND DENSE CONDITION

This study has demonstrated the relationship of Clayey SILT and Silty SAND due to the grain size fraction, moisture content, density and variations in loose and dense soil 
condition. The behaviour of the ERV due to the BPP was also analysed and presented using statistical regression method in Figures 4 and 7 .

Based on Table 2, it was found that the ERV of Silty SAND (Loose: 600 - $7300 \Omega \mathrm{m} \&$ dense: 490 - $7900 \Omega \mathrm{m}$ ) was higher than Clayey SILT (Loose: 13 - 7700 \& dense: 14 - $8400 \Omega \mathrm{m})$. Based on grain size fraction, Silty SAND dominantly consists of coarse soil $(60.09 \%)$ while Clayey SILT was mainly composed from fine soil $(78.90 \%)$. According to previous research, the ease of current to propagate within each geomaterial can be influenced by grain size fraction as fine particle will allow current to easily propagate thus produce low resistivity value while coarse grain fraction will produce high resistivity value due to the difficulty of current propagation. According to Telford et al.(1990), current may propagate in geomaterials based on electrolysis conduction where the propagation is by ionic conduction from amount and conductivity of dissolved minerals present. In mineral composition of soil, Clayey SILT has a higher composition of fine particle with particular reference to clay minerals such as kaolinite, illite, montmorillonite and vermiculite which allows the ease of the current propagation in the soil tested thus produces low resistivity value compared to the Silty SAND which has low composition of clay with high composition of coarse soil. Furthermore, as reported by Abidin et al. (2012), resistivity data exhibits a low value for fine soil such as clayey and silty while the coarser soil such as sand and gravel will produce a higher resistivity value.

Based on this study, it was found that the behaviour of ERV was greatly influenced by moisture content and density in different state of soil denseness. According to Abidin et al. (2013), a quantitative proportion of water and geomaterial particle fractions were observed to be very sensitive to influent soil resistivity data. It was found that both correlations (ERV with $\mathrm{w}$ and $\rho_{\text {bulk }}$ ) showed a curvilinear trend as given in Figures $4-7$. According to Figures $4-7$, moisture content and bulk density value were higher with the decrement of soil electrical resistivity value due to the presence of higher water content in soil tested. This findings was in line from the previous findings which indicates that the moisture content value will increase with the decrement of soil resistivity value (Abidin et al. 2014c; Cosenza et al. 2006; Ozcep et al. 2010; Rinaldi \& Cuestas 2002; Siddiqui \& Osman 2012) represented by general relationship of ERV $\infty 1 / \mathrm{w}$. When water was added continuously from dry condition until it reached saturated and oversaturated condition, the ease of current propagation in soil will be increased, thus produced high to low resistivity value. As reported by Tezel and Ozcep (2003), ions in pore fluid are difficult to propagate in low moisture content soil thus produce a low soil conductivity which will cause an increment of resistivity value. Clayey SILT has good ability to absorb higher water $\left(\mathrm{w}_{\text {loose }}: 7.76\right.$ - $100 \% \& \mathrm{w}_{\text {dense }}: 5.22-93.70 \%$ ) due to its high quantity of fine soil (Clay and Silt) thus promotes the reduction of the ERV value compared to the Silty SAND which has less fine soil with high coarse grain soil ( $\mathrm{w}_{\text {loose }}: 17.66-61.07 \%$ $\left.\& \mathrm{w}_{\text {dense }}: 9.80-59.05 \%\right)$. Hence, the ERV of Clayey SILT were obtained lower than Silty SAND due to its higher water absorbance ability which relative to the composition of the particle size fraction.

Both soils were tested under loose and dense conditions which are able to influent the ERV due to various soil densities. Based on this study, soil density value of dense condition was higher than loose condition because dense condition required more soil quantity than loose condition. During the compaction process, volume of air contained in pore was decreased thus required an additional soil added and compacted for three layers until it was fully fit inside the box volume. Hence, the amount of soil used was higher compared to the loose conditions thus contributed to the increment in the value of bulk density. Under loose condition, soil consists of high voids which dominantly filled by air and water contributed to a lower weight thus contributed to the decrement in the bulk density value. It was found that the moisture content value for the dense condition was less than loose condition due to the least amount of water contained in a compacted soil. During dense state, soil will reduce its porosity which resulted in a decrement in the moisture content amount. However in loose state, a lot of pores were filled by water which increased the soil moisture content value. Diagram of soil particles and air with water before and after compaction effort is illustrated in Figure 8.

Generally, both soils demonstrated that ERV was high at low soil density and vice versa. This condition has shown that under low soil density, soil porosity was filled by air thus produced high ERV. According to Jusoh (2010), air filled with void possesses a higher resistivity value compared with the water filled with void. Both soils were tested from dry-moist-saturated-oversaturated condition using 1-3\% of water continuously until 25 times under loose condition. Hence, the quantity of water was greatly increased which also increasing the soil bulk density that finally produced low ERV when the experiment has passed

TABLE 2. ERV with soil moisture content and density results

\begin{tabular}{lcccc}
\hline Type of soil & \multicolumn{2}{c}{ Clayey SILT } & \multicolumn{2}{c}{ Silty SAND } \\
\hline Soil condition & Loose & Dense & Loose & Dense \\
\hline Electrical resistivity value, $\rho(\Omega \mathrm{m})$ & $13-7700$ & $14-8400$ & $600-7300$ & $490-7900$ \\
Moisture content, w $(\%)$ & $7.76-100$ & $5.22-93.70$ & $17.66-61.07$ & $9.80-59.05$ \\
Bulk density, $\rho_{\text {bulk }}\left(\mathrm{Mg} / \mathrm{m}^{3}\right)$ & $1.00-1.69$ & $1.96-2.58$ & $1.77-2.66$ & $2.16-2.80$ \\
\hline
\end{tabular}


the dry-moist state at saturated-oversaturated condition. Clayey SILT consists of high fine grain particles which is able to absorb more water compared to the Silty SAND. Hence, this phenomenon was possibly influenced the relationship between ERV and soil densities.

Normally, it was expected that the ERV was supposedly to be high due to the higher soil densities. However in Clayey SILT, this hypothesis may change due to the presence of more water within the fine soils with particular reference to clay and silt particles. Hence, in Clayey SILT case, higher density can be associated with higher moisture content thus produces low ERV represented as ERV $\infty 1 / \rho$. In other words, the higher moisture content caused easy flow of current within the soil which finally produced a lower ERV. However, the value for soil density of Clayey SILT (Loose: $1.00-1.69 \mathrm{Mg} / \mathrm{m}^{3} \&$ dense: $1.96-2.58 \mathrm{Mg} / \mathrm{m}^{3}$ ) was lower than Silty SAND (Loose: $1.77-2.66 \mathrm{Mg} / \mathrm{m}^{3} \&$ dense: $2.16-2.80 \mathrm{Mg} / \mathrm{m}^{3}$ ) due to its higher quantity of fine soil. In the past, coarse soil experienced higher mass compared to the fine soil. As a result, higher ERV was produced due to the higher value of soil densities which related to the existence of large quantity of coarse soil with particular reference to sand and gravel particles within Silty SAND. As reported by Sudha et al. (2009), the bulk resistivity of soil will increase with the grain size increment since it offers more resistance to the ionic current flow. Furthermore, high granular soil will produce lower moisture content which also contributes to the increment of ERV. Hence, general relationship between ERV and soil densities of Silty SAND can be found as ERV $\infty \rho$.

This study found that ERV will continuously decrease as water was continuously added. Despite the overall continuous decrement in ERV, small inconsistency of value reduction from high to low was also recorded especially during the loose condition test. This inconsistency ERV was caused by small inconsistent quantity of soil tested for each percentage of water added due to the soil handling difficulty from dry-moist-saturated-oversaturated. The experiment was carefully performed by filling the soil (mixed thoroughly with water) inside the box without being compacted (loose condition) with the lowest possible void left. However, the workability of soil inside the box was difficult especially when it was at moist to saturated state where the soil was in a highly cohesive condition.
The problems continued when it reached saturated to oversaturated state where the quantity of soil tested varied due to the large quantity of water added. Furthermore in some cases, those relationships presented will turn inversely especially when the properties obtained were almost similar to each other. Hence, other major dissimilar properties will take place to influent the ERV. Based on Rinaldi and Cuestas (2002), detailed study related to the actual condition related to the porosity, degree of saturation, salt concentration in pore fluid, grain size, size gradation, temperature and activity can produce more accurate correlation performed from the laboratory experiment.

This study used $1-3 \%$ of water $(15,30$ and $45 \mathrm{~mL})$ since it will allow the reading for some limit and variations. For example, $1 \%$ of water will give more variations for the large resistivity value while $2-3 \%$ of water will gradually increase the variation of low resistivity value. Hence, it was found that the range of $1-3 \%$ of water was suitable to produce a soil electrical resistivity correlation with moisture content and soil density from low to high variation. According to statistical correlation, $r$ analysis performed using SPSS, the $\mathrm{r}$ value for soil moisture content and density were found to be $0.611\left(\mathrm{w}_{\text {Loose }}\right), 0.410$ $\left(\mathrm{w}_{\text {Dense }}\right), 0.436\left(\rho_{\text {Loose }}\right)$ and $0.436\left(\rho_{\text {Dense }}\right)$, respectively which indicates that the correlation level between ERV due to $\mathrm{w}$ and $\mathrm{Q}$ were at medium and strong strength level which further verified that the correlation of ERV due to $\mathrm{w}$ and $\varrho$ is acceptable. According to Yahaya et al. (2008), the strength of $\mathrm{r}$ can be defined to be medium and strong when the r-value varied from $0.40-0.59$ and $0.6-0.79$, respectively. Furthermore, the coefficient of determination $\left(\mathrm{R}^{2}\right)$ value was determined to be $0.5634-0.8927$ (loose state) and $0.5844-0.8853$ (dense state) which indicates that the data correlation was good when it was near to the value of 1.0. Hence, the values of soil moisture content and density of Clayey SILT and Silty SAND were applicable to be predicted based on the statistical regression equation established as given in Figures 4 - 7. Apart from the understanding of ERV behaviour due to the basic physical properties of soil, this study has developed an equation which is applicable to predict the field soil moisture content and density using resistivity value input which can be determined during field resistivity survey at the site studied. Hence, it is able
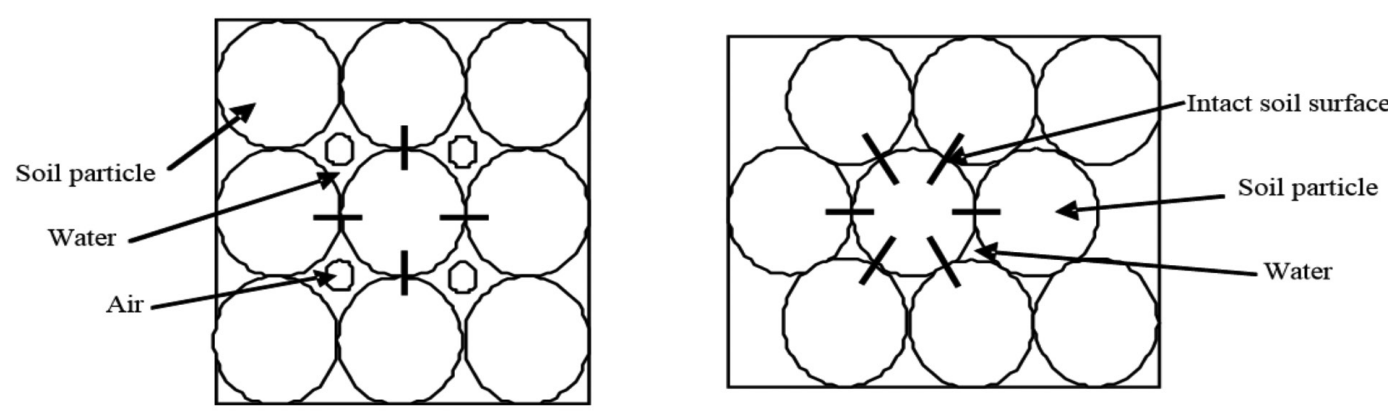

FIGURE 8. Diagram of soil particles and air with water before (left) and after (right) compaction effort 
to contribute to the ease of basic geotechnical properties determination thus able to reduce the number of soil sampling and lab test which traditionally used in practice.

Resistivity value was highly influenced by pore fluid and grain matrix of geomaterials (Griffiths \& Kings 1981). As reported by Liu and Evett (2008), ERV soil generally varied inversely proportional to the water content and dissolved ion concentration as clayey soil exhibited high dissolved ion concentration, wet clayey soils have lowest resistivity of all soil materials while coarse, dry sand and gravel deposits and massive bedded and hard bedrocks have the highest ERV. Furthermore, the decrement of ERV was resulted from an increment of metal ions or inorganic elements in geomaterials (Jung \& Ha 2000). According to Friedel et al. (2006), soil parameters determined in grain size analysis could replicate the variety of resistivity obtained on the site very well. Hence, this study is able to explain and predict various values of ERV due to the variation of selected soil physical state. In other words, basic physical properties of soil was strongly able to influent ERV due to the soil composition variation which relative to the quantity of solid, air and water whether in loose and dense condition.

\section{CONCLUSION}

The ERV from laboratory test was successfully established on Clayey SILT and Silty SAND soil in loose and dense condition. This study has showed that the ERV was largely influenced by the variations of soil basic physical properties (BPP) with particular reference to particle size fraction, moisture content and density of soil. As a result, this study has reduced few of the black boxes (uncertainties) of the ERV interpretation ambiguity through some of the relationship theories between ERV and BPP. Hence, this study has demonstrated that the integral analysis between ERV with BPP can contribute a meaningful contribution for ERV result interpretation and prediction since it is able to explain, justify and verify the behavior of ERV based on basic physical properties of soil through quantitative perspectives.

\section{ACKNOWLEDGEMENTS}

This work was funded by Universiti Tun Hussein Onn Malaysia (IGSP from vot. U258), Universiti Sains Malaysia and the Ministry of Higher Education (MOHE), Malaysia. First author wish to acknowledge gratefully to supervisors and research members for their tremendous guidance, work and cooperation.

\section{REFERENCES}

Abdallatif, T., Khafagy, A.A.B. \& Khozym, A. 2015. Geophysical investigation to delineate hazardous cavities in Al-Hassa karstic region, Kingdom of Saudi Arabia. Engineering Geology for Society and Territory 5: 507-514.

Abidin, M.H.Z., Baharuddin, M.F.T., Zawawi, M.H., Ali, N.A.M., Madun, M. \& Tajudin, S.A.A. 2015. Groundwater seepage mapping using electrical resistivity imaging. Applied Mechanics and Materials 773-774: 1524-1534.

Abidin, M.H.Z., Saad, R., Wijeyesekera, D.C. \& Ahmad, F. 2014a. Soil resistivity influence due to the different utilization of electrical resistivity array. Electronic Journal of Geotechnical Engineering 18: 5643-5654.

Abidin, M.H.Z., Saad, R., Wijeyesekera, D.C., Ahmad, F. \& Ismail, N.A. 2014b. The influence of electrical resistivity array on its soil electrical resistivity value. Applied Mechanics and Materials 510: 185-192.

Abidin, M.H.Z., Saad, R., Ahmad, F., Wijeyesekera, D.C. \& Baharuddin, M.F.T. 2014c. Correlation analysis between field electrical resistivity value (ERV) and basic geotechnical properties (BGP). Soil Mechanics and Foundation Engineering 51: 117-125.

Abidin, M.H.Z., Wijeyesekera, D.C., Saad, R. \& Ahmad, F. 2013. The influence of soil moisture content and grain size characteristics on its field electrical resistivity. Electronic Journal of Geotechnical Engineering 18: 699-705.

Abidin, M.H.Z., Saad, R., Ahmad, F., Wijeyesekera, D.C. \& Baharuddin, M.F.T. 2012. Integral analysis of geoelectrical (resistivity) and geotechnical (spt) data in slope stability assessment. Academic Journal of Science 1: 305-316.

Abu-Shariah, M.I.I. 2009. Determination of cave geometry by using a geoelectrical resistivity inverse model. Engineering Geology 105: 239-244.

Afshar, A., Abedia, M., Norouzia, G. \& Riahib, M. 2015. Geophysical investigation of underground water content zones using electrical resistivity tomography and ground penetrating radar. A case study in Hesarak-Karaj, Iran: Engineering Geology 196: 183-193.

Aktürk, O. \& Doyuran, V. 2015. Integration of electrical resistivity imaging (ERI) and ground-penetrating radar (GPR) methods to identify soil profile around Necatibey Subway Station, Ankara, Turkey. Environmental Earth Sciences 74(3): 2197-2208.

Al-Sabahi, E., Samsuddin, A.R., Yaacob, W.Z.W. \& Hamzah, U. 2008. 2D electrical resistivity investigation at Ampar Tenang Landfill Site, Selangor D.E. Sains Malaysiana 37(1): 33-37.

Anita, T. 2005. Water content and porosity estimated from ground-penetrating radar and resistivity. Journal of Applied Geophysics 58: 99-111.

Baharuddin, M.F.T., Othman, A.R., Taib, S., Hashim, R., Abidin, M.H.Z. \& Radzuan, M.A. 2013. Evaluating freshwater lens morphology affected by seawater intrusion using chemistryresistivity integrated technique: A case study of two different land covers in Carey Island, Malaysia. Environmental Earth Sciences 69: 2779-2797.

Benson, R.C., Yuhr, L. \& Kaufmann, R.D. 2003. Some considerations for selection and successful application of surface geophysical methods. Proceedings of the $3 \mathrm{rd}$ Int. Conference on Applied Geophysics.

Billi, A., Filippis, L.D., Poncia, P.P., Sellad, P. \& Faccenna, C. 2016. Hidden sinkholes and karst cavities in the travertine plateau of a highly-populated geothermal seismic territory (Tivoli, central Italy): Geomorphology 255: 63-80.

British Standard 1377. 1990. Methods of test for Soils for Civil Engineering Purposes.

Burger, H.R., Sheehan, A.F. \& Jones, C.H. 2006. Introduction to Applied Geophysics. New York: W.W. Norton \& Company.

Clayton, C.R.I., Matthews, M.C. \& Simons, N.E. 1995. Site Investigation. London: Blackwell Science Ltd. 
Cosenza, P., Marmet, E., Rejiba, F., Jun Cui, Y., Tabbagh, A. \& Charlery, Y. 2006. Correlations between geotechnical and electrical data: A case study at Garchy in France. Journal of Applied Geophysics 60: 165-178.

Cuong,L.P., Tho, L.V., Juzsakova, T., Rédey, A. \& Hai, H. 2016. Imaging the movement of toxic pollutants with 2D electrical resistivity tomography (ERT) in the geological environment of the Hoa Khanh Industrial Park, Da Nang, Vietnam. Environmental Earth Sciences 75: 286.

Ebraheem, A.M., Mulla, M.M.A., Sherif, M.M., Awad, O., Akram, S.F., Suweidi, N.B.A. \& Shetty, A. 2014. Mapping groundwater conditions in different geological environments in the northern area of UAE using 2D earth resistivity imaging survey. Environmental Earth Sciences 72(5): 1599-1614.

Fragaszy, R., Santamarina, J., Amekudzi, A., Assimaki, D., Bachus, R., Burns, S., Cha, M., Cho, G., Cortes, D., Dai, S., Espinoza, D., Garrow, L., Huang, H., Jang, J., Jung, J., Kim, S., Kurtis, K., Lee, C., Pasten, C., Phadnis, H., Rix, G., Shin, H., Torres, M. \& Tsouris, C. 2011. Sustainable development and energy geotechnology - Potential roles for geotechnical engineering. KSCE Journal of Civil Engineering 15: 611-621.

Fraiha, S.G.C. \& Silva, J.B.C. 1994. Factor analysis of ambiguity in geophysics. Geophysics 59: 1083-1091.

Friedel, S., Thielen, A. \& Springman, S.M. 2006. Investigation of a slope endangered by rainfall-induced landslides using $3 \mathrm{D}$ resistivity tomography and geotechnical testing. Journal of Applied Geophysics 60: 100-114.

Godio, A., Strobbia, C. \& de Bacco, G. 2006. Geophysical characterisation of a rockslide in an Alpine region. Engineering Geology 83: 273-286.

Griffiths, D.H. \& King, R.F. 1981. Applied Geophysics for Geologist and Engineers- The Element of Geophysical Prospecting. Oxford: Pergamon Press.

Hafez, M.A., Atya, M.A., Hassan, A.M., Sato, M., Wonik, T. \& El-Kenawy, A.A. 2008. Shallow geophysical investigations at the Akhmim archaeological site, Suhag, Egypt. Applied Geophysics 5(2): 136-143.

Hajizadeh, F. \& Akhondi, S.R. 2016. Determining aquifers and bedrock of Qaen plain by the resistance measurement method. Modern Applied Science 10(1): 200-206.

Hamzah, U., Bahrudin, N.F.D.B., Ismail, M.A. \& Abbas, B.I.N.A.A. 2009b. Survei pengimejan elektrik dan georadar dalam kajian tanah runtuh Taman Hill View, Ampang, Selangor. Sains Malaysiana 38(3): 305-311.

Hamzah, U., Ismail, M.A. \& Samsudin, A.R. 2009c. Geoelectrical resistivity and ground penetrating radar techniques in the study of hydrocarbon-contaminated soil. Sains Malaysiana 38(3): 305-311.

Hamzah, U., Samsudin, A.R., Rafek, A.G. \& Razak, K.A. 2009a. Kemasinan air perigi dan subpermukaan lembangan tuba Langkawi dengan analisis hidrokimia dan survei keberintangan elektrik menegak. Sains Malaysiana 38(6): 851-856.

Hamzah, U. \& Chieh, C.S. 2008. Penyiasatan infiltrasi bahan larut resap di sekitar tapak pelupusan sampah ampar tenang, dengkil. Sains Malaysiana 37(2): 161-168.

Hamzah, U., Samsudin, A.R. \& Malim, E.P. 2006b. Soil and groundwater investigation in Kuala Selangor coastal plain using geoelectrical and geochemical surveys. Sains Malaysiana 35(1): 11-18.

Hamzah, U., Sirat, D.S. \& Muzafar, N. 2006a. Pemetaan akuifer dengan teknik geoelektrik di Sungai Kelambu, Banting, Selangor. Sains Malaysiana 35(2): 35-40.
Hawamdeh, A., Jaradat, R. \& Alsaad, Z. 2015. Integrated application of geophysical methods for investigation of the Al-Berktain archaeological site in the city of Jerash, Jordan. Environmental Earth Sciences 73(7): 3665-3674.

Hazreek, Z.A.M., Rosli, S., Chitral, W.D., Fauziah, A., Azhar, A.T.S., Aziman, M. \& Bakar, I. 2015. Soil identification using field electrical resistivity method. Journal of Physics: Conference Series 622: 012030.

Hsua, H., Yanitesb, B.J., Chena, C. \& Chenc, Y. 2009. Bedrock detection using 2D electrical resistivity imaging along the Peikang River, central Taiwan. Geomorphology 114: 406-414.

Jeeva, M. \& Hamzah, U. 2012. Kajian migrasi bahan larut resap di tapak pelupusan sampah Sungai Dedu, Telok Datuk dengan kaedah geofizik dan geokimia. Sains Malaysiana 41(7): 829-840.

Jung, Y., Lee, Y. \& Ha, H. 2000. Application of electrical resistivity imaging techniques to civil and environmental problems. Use of Geophysical Methods in Construction 2000: 52-64.

Jusoh, Z. 2010. Application of 2-D resistivity imaging and seismic refraction technique in subsurface investigation for civil engineering. MSc. Thesis, Sch. Science Universiti of Malaysia (Unpublished).

Khatri, R., Shrivastava, V.K. \& Chandak, R. 2011. Correlation between vertical electric sounding and conventional methods of geotechnical site investigation. International Journal of Advanced Engineering Sciences and Technologies 4: 042053.

Liu, C. \& Evett, J.B. 2008. Soils and Foundation. New Jersey: Pearson International.

Liu, Z., Liu, S., Cai, Y. \& Fang, W. 2015. Electrical resistivity characteristics of diesel oil-contaminated kaolin clay and a resistivity-based detection method. Environmental Science and Pollution Research 22(11): 8216-8223.

Margiotta, S., Negri, S., Parise, M. \& Quarta, T.A. M. 2015. Evaluating the potentialities of hydro-stratigraphic, geomorphological and geophysical analyses to detect underground cavities. Engineering Geology for Society and Territory 5: 559-562.

Martínez-Pagán, P., Gómez-Ortiz, D., Martín-Crespo, T. \& Manteca, J.I. 2010. Detecting the occurrence of shallow mining cavities by electrical resistivity imaging method. A study case on the Victoria Cave, Cartagena (SE Spain). Proceedings of SEG Annual Meeting.

Masrom, S.N., Arifin, M.H., Harun,A.R. \& Samsudin,A.R. 2011. Survei keberintangan geoelektrik untuk mengesan terowong di Bukit Tenggek, Setiu, Terengganu. Sains Malaysiana 40(11): 1223-1229.

Mauritsch, H.J., Seiberl, W., Arndt, R., Römer,A., Schneiderbauer, K. \& Sendlhofer, G.P. 2000. Geophysical investigations of large landslides in the carnic region of Southern Austria. Engineering Geology 56: 373-388.

Moghaddam, S., Dejpasand, S., Rohani, A.K., Parnow, S. \& Ebrahimi, M. 2015. Detection and determination of groundwater contamination plume using time-lapse electrical resistivity tomography (ERT) method. Journal of Mining and Environment 8(1): 103-110.

Mohamed, N., Hamzah, U. \& Sahibin, A.R. 2009. Kepekatan kandungan logam berat dalam tanih di tapak pelupusan sampah Sg. Kembong, Bangi, Selangor. Sains Malaysiana 38(6): 841-850

Nouioua, I., Fehdi, C., Boubaya, D., Serhane, B. \& Djellali, A. 2015. Mapping underground cracks using 2D electrical resistivity tomography: The case of the landslide of Kef 
Essenoun phosphate deposit, Djebel Onk (northeast of Algeria). Arabian Journal of Geosciences 8(10): 7731-7738.

Ozcep, F., Yildirim, E., Tezel, O., Asci, M.\& Karabulut, S. 2010. Correlation between electrical resistivity and soil-water content based artificial intelligent techniques. International Journal of Physical Sciences 5(1): 047-056.

Reci, H., Jata, I. \& Bushati, S. 2015. Ert method for the detection of buried archaeological objects in Apollonia \& Bylis, Albania. Romanian Reports in Physics 67(2): 665-672.

Rinaldi, V.A. \& Cuestas, G. 2002. Ohmic conductivity of a compacted silty clay. Journal of Geotechnical and Geoenvironmental Engineering 128(10): 824-835.

Saad, R., Muztaza, N.M. \& Mohamad, E.T. 2011. The 2D electrical resistivity tomography (ERT) study for civil and geotechnical engineering purposes. Electronic Journal of Geotechnical Engineering 16: 1537-1545.

Samsudin, A.R., Hamzah, U. \& Ramli, Z. 2007. An integrated geophysical study of the quaternary basin at Olak Lempit Banting Area, Selangor, Malaysia. Sains Malaysiana 36(2): 159-163.

Sass, O. 2007. Bedrock detection and talus thickness assessment in the European Alps using geophysical methods. Journal of Applied Geophysics 62(3): 254-269.

Schoor, M.V. 2002. Detection of sinkholes using 2D electrical resistivity imaging. Journal of Applied Geophysics 50: 393-399.

Siddiqui, F.I. \& Osman, S.B.A.S. 2012. Integrating geo-electrical and geotechnical data for soil characterization. International Journal of Applied Physics and Mathematics 2: 104-106.

Sirhan, A.\& Hamidi, M. 2016. Detection of soil and groundwater domestic pollution by the electrical resistivity method in the West Bank, Palestine. Near Surface Geophysics 11(4): 371- 380.

Solberg, I.L., Hansen, L., Rønning, J.S., Haugen, E.D., Dalsegg, E. \& Tønnesen, J. 2011. Combined geophysical and geotechnical approach to ground investigations and hazard zonation of a quick clay area, Mid Norway. Bulletin of Engineering Geology and the Environment 71: 119-133.

Sudha, K., Israil, M., Mittal, S. \& Rai, J. 2009. Soil characterization using electrical resistivity tomography and geotechnical investigations. Journal of Applied Geophysics 67: 74-79.

Taioli, F., Marchioreto, A., Machado, R. \& Gallas, J.D. F. 2009. Boulders mapping by using resistivity imaging survey. 11th International Congress of the Brazilian Geophysical Society.
Telford, W.M., Geldart, L.P. \& Sheriff, R.E. 1990. Applied Geophysics. Cambridge: Cambridge University Press.

Terrón, J.M., Mayoral, V., Salgado, J.A., Galea, F.A., Odriozola, V.H.C., Mateos, P. \& Pizzo, A. 2015. Use of soil apparent electrical resistivity contact sensors for the extensive study of archaeological sites. Archaeological Prospection 22(4): 269-281.

Tezel, O.\& Ozcep, F. 2003. Relationships of electrical resistivity and geotechnical parameters. Proceedings of Conference on Earth Sciences and Electronics, Istanbul, Turkey.

Whitlow, R. 2001. Basic Soil Mechanics. Dorset: Prentice Hall.

Yahaya, A.S., Ahmed, A., Gabda, D. \& Na, C.S. 2008. Problem and Solution in Statistics for Engineers and Scientist. Selangor: Prentice Hall.

Mohd Hazreek Zainal Abidin*, Devapriya Chitral Wijeyesekera, Mohamad Faizal Tajul Baharuddin, Saiful Azhar Ahmad Tajudin \& Aziman Madun

Faculty of Civil and Environmental Engineering

Universiti Tun Hussein Onn Malaysia 86400 Batu Pahat, Johor Darul Takzim Malaysia

Rosli Saad

School of Physics, Universiti Sains Malaysia

11800 USM Penang, Pulau Pinang

Malaysia

Fauziah Ahmad

School of Civil Engineering

Universiti Sains Malaysia

14300 Nibong Tebal, Pulau Pinang

Malaysia

*Corresponding author; email; hazreek@uthm.edu.my

Received: 12 March 2016

Accepted: 28 March 2017 